\title{
Assessment of geochemical barriers at preservation of low-level radioactive waste storages
}

\author{
Anatoly Boguslavsky ${ }^{1}$, Olga Gaskova ${ }^{1,2}$, and Olga Naymushina ${ }^{1}$ \\ ${ }^{1}$ Sobolev Institute of Geology and Mineralogy, Siberian Branch of Russian Academy of Sciences, 630090, Novosibirsk, Russia \\ ${ }^{2}$ Novosibirsk State University, 630090, Novosibirsk, Russia
}

\begin{abstract}
The work considers geochemical aspects of the natural and man-made system for storing radioactive waste (RW) from one of the Siberian enterprises of the fuel and nuclear cycle. Careful geochemical testing of key sites of the system allows us to identify geochemical barriers that prevent the spread of uranium outside the sludge storage. In addition, experiments were conducted on the leaching of the sludge material in the laboratory using modern methods for determining the composition of solutions and solid phases, as well as experiments on uranium sorption on the main types of subsoil. Experimental and thermodynamic modeling of uranium deposition processes confirms that the system studied satisfactorily copes with the absorption of uranium taken out of the sludge storage due to dilution and sorption on rocks and bottom sediments. Particularly favorable are bottom sediments rich in organic matter, which bind uranium to organic-mineral complexes.
\end{abstract}

\section{Introduction}

The modern concept of handling low-level radioactive waste (LLRW) is to create a multi-barrier system that prevents the spread of radionuclides outside the storage facilities. Both natural and man-made structures can act as barriers to safety, which either detain pollutants due to low filtration rates or increased sorption characteristics [1-3]. With the preservation of sludge storage facilities that were designed dozens of years ago, the reliability of natural barriers is of particular importance [4-6]. Determination of reliability and sufficiency of the existing safety barriers in the future requires creation of a migration model for leading pollutants based on geological, hydrogeological and geochemical features of the site [7-9].

\subsection{Object of investigation}

The tail facility of OAO Novosibirsk Plant of Chemical Concentrates (NPCC) is located in several kilometers from city line of Novosibirsk.

Processing of ores and concentrates from 1954 to 1962 was carried out according to the acid-soda scheme and the waste products of the production were ore sands and a pulp of hydrated cakes. After 1962, the plant stopped processing ore, as raw materials there began to receive already purified and enriched uranium, devoid of the daughter elements, so carbonate uranyl became the main waste product.

The main masses of slurries of NPCCs are the tails of hydrated cakes. They are dominated by gypsum $60 \%$, uranium content $0.13 \%$, calcite, sulphates such as ettringite, bentorite, Fe oxides, amorphous phases, traces of sodium aluminate, chlorite are present. The individual mineral phases of uranium are absent. Uranium is in the form of isomorphic inclusions in carbonates and sulphates (including in gypsum). Samples of hydrate cakes of sandy and silt fractions (ore sand) contain primary grains of uraninite up to $0.5 \mathrm{~mm}$ in size.

The upper part of the geological section in the studied area is represented by overlapped Middle Quaternary formations. Directly on the site a unit of clay loams with a thickness of 3-9 $\mathrm{m}$ is distinguished by a weak water permeability $(<0.001 \mathrm{~m} /$ day $)$. They are the main water reservoir for groundwater in the area of the sludge storage. Above lie clay loams, interbedded with sandy clays and fine-grained sands. Their thickness is about $4 \mathrm{~m}$ and is characterized by increased water permeability $(0.1 \div 0.3 \mathrm{~m} /$ day, up to $1.5 \mathrm{~m} /$ day $)$. Sandy clays and sands are the most water-permeable soils in the area of tailings, and confine the main flow of groundwater.

Until creation of the tailings dam, the Pashensky ravine represented a deep, ragged ravine with a seasonal watercourse. After the creation of the technical dam, its thalweg is intensely swamped all the way to the Lake Kachimovskoye due to the increase in moisture stagnation and modern peat deposits filling underlying bed. In bottom formation of the ravine under the RW body, peat deposits were opened by drilling; their thickness in the thalweg is about one meter.

To determine the extent of migration and the redistribution of pollutants towards a distance from the sludge storage, approbation of surface and groundwater, bottom sediments and rocks of the technogenic system 
NPCC - Lake Kachimovskoye - Lake Fonovoe and Lake Gniloe is carried out.

\subsection{Methods}

The determination of the elemental composition of solid samples was carried out by the XRF method at the elemental analysis station VEPP-3 of the Institute of Nuclear Physics of the SB RAS. Uranium forms were determined using an electronic scanning microscope Tescan MIRA 3 LMU. The mineral composition of the samples was defined by X-ray powder diffractometry on a DRON-3 diffractometer. The analysis of the elemental composition of solutions was carried out in the analytical center of IGM SB RAS using high-resolution inductively coupled plasma (ICP MS) mass spectrometry on an instrument manufactured by FINNIGAN MAT (Germany). The concentrations of anions were determined by titrimetric, turbidimetric, potentiometric methods. The species of uranium were determined by the sequential extraction procedure according to the scheme proposed in [10], which is a modified version of the Tessier scheme [11]. In this case, the water-soluble and exchangeable fractions are classified as readily mobile, while the carbonate is the nearest reserve, which is activated when the physico-chemical conditions and chemical compositions in the water/rock system $(\mathrm{pH}$, pCO2, etc.) change.

Thermodynamic calculations in the heterophase 27component H-O-C-Sl-N-S-Al-Si-Na-Ca-Mg-Mn-Fe-U$\mathrm{Pu}-\mathrm{Am}-\mathrm{Ru}-\mathrm{Cs}-\mathrm{So}-\mathrm{Ni}-\mathrm{Mo}-\mathrm{Zr}-\mathrm{Cu}-\mathrm{Zn}-\mathrm{Cd}-\mathrm{Ba}-\mathrm{Sr}$ system were carried out at $25^{\circ} \mathrm{C}$ and a total pressure of $1 \mathrm{~atm}$. by the GIBBS algorithm using the built-in thermodynamic bank UNITHERM of the HCh software package [12].

\section{Results and discussion}

\subsection{Water chemical composition}

According to chemical analyses of a surface water of the studied area, background concentration of chlorine (up to $2173 \mathrm{mg} / \mathrm{L}$ ), sulfates (up to $1019 \mathrm{mg} / \mathrm{L}$ ), sodium (up to $1418 \mathrm{mg} / \mathrm{L})$, uranium $(0.75 \mathrm{mg} / \mathrm{L})$ are exceeded. However, in the process of removal from the sludge collector, the TDS and gradually decreases, $\mathrm{pH}$ value increases from 6.5 to 7.5. The general concentration of uranium also decreases to $0.0004 \mathrm{mg} / \mathrm{L}$ (Table 1).

\subsection{Distribution of uranium species and sorption experiments}

The finding of the sludge collector in the thalweg of the natural ravine causes the probability of flooding the storage with groundwater. The interaction of groundwater with radioactive waste consists of the following links: groundwater flow into the storage and interact with radioactive waste $\rightarrow$ interaction of contaminated water with peat $\rightarrow$ interaction of contaminated water with clay loam of eluvial cover $\rightarrow$ post-treatment of water in the permeable layer of sand and sandy loam.

To determine the scale of possible removal of uranium, its species in various rocks was determined (Table 2). The rocks were saturated with uranium and then subjected to leaching. It turned out that about $36 \%$ of uranium from peat passes into solution, but up to $60 \%$ is firmly retained in the solid phase $(42 \%$ with carbonates and $16.9 \%$ directly with organics). In this case, the carbonate form predominates in all types of the boggy ravine, amounting to at least $40 \%$ (Table 3 ).

Table 2. Definition of uranium species in the main types of subsoil, \%

\begin{tabular}{|c|c|c|c|c|}
\hline $\begin{array}{l}\text { Sequential } \\
\text { extraction procedure }\end{array}$ & Sand & $\begin{array}{l}\text { Clay } \\
\text { loam } \\
\text { soil }\end{array}$ & Peat & Clay \\
\hline Water-soluble & 2.9 & 1.3 & 35.7 & 19.1 \\
\hline Exchangeable & 20.3 & 21.7 & 0.9 & 21.3 \\
\hline Carbonate & 53.1 & 58.6 & 42.4 & 40.2 \\
\hline $\begin{array}{l}\text { Bound to } \mathrm{Fe} / \mathrm{Mn} \\
\text { oxides }\end{array}$ & 1.7 & 1.6 & 2.3 & 1.1 \\
\hline $\begin{array}{l}\text { Bound to organic } \\
\text { matter }\end{array}$ & 11.8 & 8.4 & 16.9 & 6.5 \\
\hline Residual & 10.3 & 8.3 & 1.9 & 11.9 \\
\hline
\end{tabular}

Table 3. The results of experiments on the sorption of uranylion (a sample of sorbent $1 \mathrm{~g}$, a solution of $50 \mathrm{ml}$ )

\begin{tabular}{lllll}
\hline $\begin{array}{l}\mathrm{U}_{\text {initial }}, \\
\mathrm{mg} / \mathrm{L}\end{array}$ & $\begin{array}{l}\text { Concentration in subsoil } \\
\text { after sorption, }\end{array}$ & $\begin{array}{l}\text { Uranium } \\
\text { on subsoil, } \%\end{array}$ \\
\cline { 2 - 5 } & $\begin{array}{l}\text { Clay loam } \\
\text { soil }\end{array}$ & Sand & $\begin{array}{l}\text { Clay loam } \\
\text { soil }\end{array}$ & Sand \\
10 & 1469 & $164-311$ & 74.9 & $8.4-15.5$ \\
1 & 142 & $22-23$ & 74.7 & $11.9-12.3$ \\
0.1 & 18.8 & $5.5-7.9$ & 98.9 & $28.3-51.9$ \\
0.01 & 2.1 & $0.46-0.8$ & 95.5 & $48.1-81.9$ \\
0.001 & 0.15 & $0.05-0.06$ & 87.2 & $67.6-84$ \\
\hline
\end{tabular}

Table 1. Chemical composition of surface waters with distance from the slime pit, $\mathrm{mg} / \mathrm{L}$

\begin{tabular}{|c|c|c|c|c|c|c|c|c|c|c|c|c|c|}
\hline Site & $\mathrm{pH}$ & $\mathrm{Cl}^{-}$ & $\mathrm{HCO}_{3}^{-}$ & $\mathrm{SO}_{4}{ }^{2-}$ & $\begin{array}{l}\text { Conductivity, } \\
\mu \mathrm{Sm} / \mathrm{cm}^{2}\end{array}$ & $\begin{array}{l}\text { TDS, } \\
\text { g/L }\end{array}$ & $\mathrm{Na}$ & $\mathrm{Mg}$ & $\mathrm{Ca}$ & $\mathrm{Mn}$ & $\mathrm{Fe}$ & $\mathrm{Sr}$ & $\mathrm{U}$ \\
\hline $\begin{array}{l}\text { At the output of } \\
\text { the slime pit } \\
\text { Kachimovskoe }\end{array}$ & 6.5 & 2173 & 98 & 1018 & 8996 & 13.17 & 1418 & 152 & 1334 & 38 & 0.62 & 6.5 & 0.75 \\
\hline $\begin{array}{l}\text { Lake } \\
\text { After } \\
\text { Kachimovskoe }\end{array}$ & 7.6 & 164 & 104 & 291.0 & 974.4 & 0.96 & 88 & 16 & 95 & $<0.02$ & $<0.05$ & 1.7 & 0.078 \\
\hline Lake & 8.0 & 137 & 137 & 245.0 & 907.2 & 0.87 & 76 & 16 & 90 & $<0.02$ & 0.054 & 1.4 & 0.061 \\
\hline Gniloe Lake & 7.8 & 64 & 98 & 94.5 & 464.9 & 0.39 & 34 & 12 & 41 & $<0.02$ & 0.066 & 0.68 & 0.033 \\
\hline $\begin{array}{l}\text { Fonovoe Lake } \\
\text { (background) }\end{array}$ & 7.8 & 12 & 366 & 1.6 & 471.8 & 0.32 & 7.8 & 12 & 70 & 0.008 & 0.14 & 0.55 & 0.0004 \\
\hline $\begin{array}{l}\text { Ground water } \\
\text { (background) }\end{array}$ & 7.3 & 5 & 560 & 17 & 737 & 0.76 & 6.6 & 30 & 140 & $<0.002$ & 0.05 & 1.27 & 0.002 \\
\hline
\end{tabular}


A cover layer of natural clay loam is of great importance for preventing the spread of uranium (whereas in clays it turned out to be up to $19 \%$ of the water-soluble fraction and we assume the leaching of pore solutions containing uranium). Quartz, feldspars predominate in the mineral composition of clay loams. In the finely dispersed fraction, there are also mica, chlorite, calcite, a small amount of smectite-illite. According to the experimental data, in the concentration range of solution of $1-2 \mathrm{mg} / \mathrm{L}$, they can absorb uranium up to $0.01-0.02 \%$ (Table 3). Moreover, these concentrations are close to those found in underlying clay loams, which are saturated with uranium under natural conditions (up to $160 \mathrm{ppm}$ ).

The sorption characteristics of sands are much inferior to the initial clay loams; however, considering the extent of the sandy horizon, they play an important role in the overall purification. Most of the uranium, absorbed by the sands, passes into stable forms.

\subsection{Water-rock interaction}

In slurries of NPCC (tails of hydrated cakes), gypsum predominates $60 \%$, uranium content reaches $0.13 \%$. As calculations of the saturation indices show, the equilibrium between the liquid and solid phases in the slurry storage is not reached, the solutions have an unbalanced chemical composition (many anions). We believe that the reason is the preferential precipitation of cations in the form of carbonates and oxides in alkaline solutions, up to $70 \%$ of uranium is in the form of calcium uranate $\mathrm{CaUO}_{4}(\mathrm{ORP} \sim 0.3 \mathrm{~V})$. At the same time, slurry solutions are undersaturated with respect to gypsum and other complex sulfates, to all salts of chloride and nitrate ions. Anions should be taken out by drainage solutions in groundwater under the slime storage (model calculations showed that the precipitation of $\mathrm{Cl}^{-}$and $\mathrm{NO}_{3}^{-}$is possible only by evaporating the liquid pulp fraction more than a hundredfold). The ion exchange capacity of the rocks of the region is low; the main mechanism for removing $\mathrm{Cl}^{-}$and $\mathrm{NO}_{3}{ }^{-}$is dilution with fresh solutions.

The calculated dynamic model of RW erosion by natural waters with the cessation of the intake of slimes indicates that after several tens of years the quick dissolving sulfates (gypsum, ettringite), then carbonates, fluorites will be washed out. After hundreds of years, only hydroxides and minerals of clays (chlorite, kaolinite, goethite) will be stable. The compound $\mathrm{CaUO}_{4}$ is more stable than sulphates, so after gypsum and other soluble minerals leaching, even the relative enrichment of the solid phase with uranium will occur (due to a reduction in precipitation). Upon contact of mineralized drainage solutions with underlying low peat and clay or clay loam (bottom sediments), a number of processes of uranium immobilization are observed, including coprecipitation, chemisorption, physical sorption (ion exchange).

The data of thermodynamic modeling make it possible to differentiate the contribution of each of the processes. In particular, in clay loams and clays characterized by ion exchange, up to $20 \%$ of uranium is associated with the exchange fraction, carbonates accumulate up to $50 \%$ of uranium in the composition of

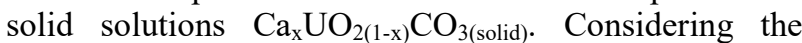
duration of contact of these soils with polluted waters (about 60 years), one can speak of a stable state of the system. After passage of organic-mineral deposits, the water comes into contact with the groundwater of the area (background). The latter are nearly neutral ( $\mathrm{pH} 7-8)$ and have a low TDS value and a hydrocarbonate-calcium composition. ORP and $\mathrm{pH}$ of contaminated and natural waters are close, therefore, when mixing solutions there are no barriers associated with oxidation-reduction and acid-base transitions. There is a gradual decrease in TDS and a change in the type of solutions from nitratechloride calcium to bicarbonate calcium only through the water/water exchange. But even in these waters there are no noticeable changes in the forms of uranium in the solution, the complex $\mathrm{Ca}_{2} \mathrm{UO}_{2}\left(\mathrm{CO}_{3}\right)_{3}$ prevails (84.4\%).

\section{Conclusions}

In the current geological and hydrogeological conditions, without additional measures for the waterproofing of structures, overlapping of slurries from above to divert meteoric waters is not enough to remove the technogenic deposit from the active water exchange zone. The intensity of uranium removal will be controlled by the amount of water interacting with radioactive waste. Given the reserve of mobile uranium, the duration of removal at existing migration rates is thousands of years. The system of geochemical barriers so far successfully copes with the spread of pollution into groundwater, but extrapolating the results for an extended period of time $(n * 100-n * 1000)$ inevitably leads to the saturation of their buffer capacity, after which the rate of uranium proliferation will increase by orders of magnitude. In this case, there is a possibility of contamination of surface water. Therefore, under the current conditions, the only alternative to the disposal of radioactive waste from the sludge storage is groundwater abstraction. The most effective way for this is to arrange a barrage in the form of a sheet-pile bulkhead around the sludge pits, which will block the flow to the groundwater storage.

This study was financially supported the Russian Foundation for Basic Research, Project №17-05-00707 (in situ sampling and lab. chemical analysis, thermodynamic modelling) and by the Russian Science Foundation, Project №18-77-10029 (definition of uranium species in solids and sorption experiments).

\section{References}

1. Michalsen M.M., Goodman B.A., Kelly S.D., Kemner K.M., McKinley J.P., Stucki J.W., Jstok J.D. Environ. Sci. Technol. 40, 7048-7053 (2006)

2. Carpenter, J., Bi Y., Hayes, K.F. Environ. Sci. Technol. 49, 1078-1085(2015)

3. De Jong W.A., Apra E., Windus T.L., Nichols J.A., Harison R.J., Gutowski K.E., Dixon D.A. J. Phys. Chem. 110, 11568-11577 (2005) 
4. McKinley J.P., Zachara J.M., Liu C., Heald S.C., Prenitzer A.I., Kempshall B.W. Geochim. Cosmochim. Acta. 70, 1873-1887 (2006)

5. Gaskova O.L., Boguslavsky A.E., Shemelina O.V. Appl. Geochem. 55, 4, 152-159 (2015)

6. Gaskova Olga L., Boguslavsky Anatoly E. Procedia Earth and Planetary Science 7, 288-291 (2013)

7. Boguslavskii, A.E., Gas'kova, O.L., Shemelina, O.V. Radiochemistry 58 3, 323-328 (2016)

8. Langmuir D. Geochim. Cosmochim. Acta 42, 547569 (1978)
9. Murakami T., Ohnuki T., Isobe H., Sato T. Am. Mineral. 82, 888-899 (1997)

10. Klemt E., Spasova Y., Zibold G., et al. Environmental Radioactivity in the Arctic and Antarctic. 67-70 (2002)

11. A. Tessier, P. G. C. Campbell, and M. Bisson. Anal. Chem., 51 7, 844-851 (1979)

12. Shvarov, Yu.V. Geochem. Int. 46 8, 834-839 (2008) 